\title{
Developing Android-Based Marbles Game Comics Using Group Investigation Model in Physics Learning
}

\author{
Almira Eka Damayanti ${ }^{1, *}$ Heru Kuswanto ${ }^{2}$ \\ ${ }^{I}$ Graduate Program, Universitas Negeri Yogyakarta. Colombo 1 Street, Karangmalang, Sleman, Special Region of \\ Yogyakarta, 55281 \\ ${ }^{2}$ Graduate Program, Universitas Negeri Yogyakarta. Colombo 1 Street, Karangmalang, Sleman, Special Region of \\ Yogyakarta, 55281 \\ "Corresponding author. Email: almiraekad@gmail.com
}

\begin{abstract}
This study aims to determine the feasibility of android-based marbles game comics using the group investigation model in learning physics. This study uses a 4-D development model (Define, Design, Develop, and Disseminate). The research data were obtained from the results of the product feasibility assessment by material experts and media experts ( 1 expert lecturer, 2 physics teacher, and 4 peer reviewers), as well as student response questionnaires. The results of the assessment based on material and media experts are in the very good category. Assessment of students' responses to comics developed on impulse momentum material with good categories. In other words, the developed comics are suitable for use in physics learning on impulse momentum material. The characteristics of the comics that were developed were using the group investigation model and integrated indigenous (marble games)..
\end{abstract}

Keywords: Android-Based Comic, Group Investigation, Indigenous: Marble Game, Physics Learning.

\section{INTRODUCTION}

The era of the industrial revolution 4.0 requires educators to be able to take advantage of technology in the learning process. One of the technologies that are developing rapidly today is the existence of a gadget called a smartphone [1]. The use of smartphones has become a common sight in our society, no matter which class, with any work background, even from any age group [2], [3]. Currently, most students spend their time using technology such as smartphones on an Android basis [4],[5] tablets, computers, and other forms, but the use of technology in the form of educational applications are still not widely used. Most students only use gadgets for games, entertainment, and social media [6]. When in fact the use of this Android can overcome limitations and problems in learning [7], [8].

Students have been wrong about assumptions about physics. Students assume that learning physics is not easy [9]. Generally, the methods and methods of learning carried out by educators in the classroom when teaching physics are usually boring and also not in accordance with the wishes of current students [10]. The concept of physics that is abstract, makes many students less interested in physics lessons [11]. Based on the results of the National examination in $2017 / 2018$, it can be seen from the results of the percentage of correct answers by high school students in Yogyakarta City for physics subjects on the material of impulse momentum absorption in provinces and nationally, namely 45.12 and 39.14. The results of the data that have been obtained show that the students' mastery of the concept of impulse momentum still needs to be improved. Therefore we need an attractive and simple media for learning in accordance with technological developments. This learning media can be in the form of comics based on android.

Android-based comics include alternative media that can be used to make physics learning more interesting [12]. Comics were chosen to facilitate understanding and make science learning more interesting because the content is by the environment and illustrations are presented through simple images with interesting stories, containing humor, and text that is not rigid. [13]. One of the advantages of comics is that they can be used to motivate students during the learning process, where 
images made in the form of conversations between characters can improve the quality of learning. Comics can be more contextual if they are integrated with local wisdom / indigenous knowledge.

Learning activities that are associated with indigenous learning can further motivate students [2]. However, local communities who still adhere to cultural values are ignored in various fields of education, including in physics learning. [14]. One of the natives that can be integrated with physics learning is games. The traditional game itself can be used as a real contextual example of learning activities. Physics concepts that can be integrated with Indigenous such as marble games that have not been used to explain physics material as a whole but only as an example. If students have been motivated to learn, students will assess active in learning [15] So that learning will be student-centered according to the 2013 curriculum [16].

One of the learning models that can be implemented in the 2013 curriculum is the Group Investigation (GI), the learning model. The Group Investigation (GI) learning model can improve the scientific work skills of students in the learning process. Also, learning that is carried out using the Group Investigation (GI) learning model can also facilitate the limited time provided by the school [17]. So that it is expected to encourage students who are skilled in managing science and behave scientifically, where learning physics provides various learning experiences to understand the concepts and processes of science.

Android-based physics comics combine technology, knowledge, and literacy in one learning medium. This comic can be integrated with the group investigation model which is in line with the era of the industrial revolution 4.0 and the implementation of the 2013 curriculum. This comic is effective and efficient because it can be operated anytime and anywhere on the Android smartphone platform. The marbles game comic based on android using the group investigation model on learning physics for impulse-momentum material will be developed using a 4-D development model. Furthermore, comics will be tested for feasibility by material and media experts as well as students' responses to these comics. Therefore, an android based marbles game comic will be produced using the group investigation model which is suitable for use in learning physics.

\section{RESEARCH METHOD}

The research method used in this research is the research and development method or Research and Development (R\&D) with a 4-D development model. The 4D development model used in this study consists of 4 main stages, namely: Define, Design, Develop and Disseminate.

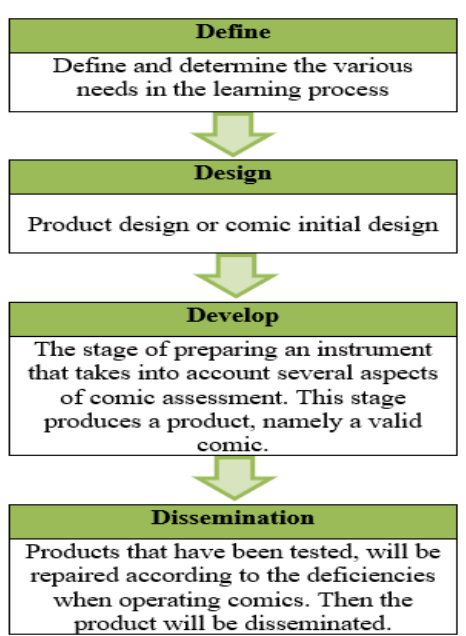

Figure 1. The 4D model development stage [18].

Techniques in collecting data in the research to be carried out consisted of interviews, observation, documentation, product feasibility assessment and student response questionnaires. Observations were made when analyzing the needs associated with student analysis and curriculum analysis. Interviews were conducted in order to obtain information, confirmation, and verification about the implementation and learning obstacles in the classroom. Assessment of the feasibility of comic products developed through the provision of questionnaires that have been validated by the validator. Student response questionnaires to find out students' responses to the products being developed.

The feasibility of comics was analyzed by looking at the score on the assessment sheet. Each question item uses a score in the range 1-4. The data in the form of Likert questions were then changed into a quantitative form. The modified data is then classified into groups of actual scores that state the feasibility level of the product to be developed. Widoyoko makes a classification with a comparison to the average ideal score $(\mathrm{Xi})$ and the ideal standard deviation score (SBi), the qualification level is divided into four categories, with the criteria as in Table 1.Calculation of the average score $(\overline{\boldsymbol{X}})$ [19]:

$\bar{X}=\frac{\sum X}{n}$

Where:

$\bar{X}$ : average score

$\sum X:$ total score

$n$ : number of appraisers

Table 1. Conversion of Scores into Categories.

\begin{tabular}{|c|c|}
\hline Average Score Range & Quality Category \\
\hline$\overline{\mathbf{X}} \geq \mathrm{Xi}+1,8 \mathrm{SBi}$ & Very good \\
\hline $\mathrm{Xi}+0,6 \mathrm{SBi} \leq \overline{\mathbf{X}} \leq \mathrm{Xi}+1,8 \mathrm{SBi}$ & Good \\
\hline
\end{tabular}




\begin{tabular}{|c|c|}
\hline$X i+1,8$ SBi $\leq \overline{\mathbf{X}} \leq \mathrm{X} 1+0,6 \mathrm{SBSi}$ & Not good \\
\hline$<\mathrm{Xi}-0,6 \mathrm{SBi}$ & Not very good \\
\hline
\end{tabular}

\section{RESULTS AND DISCUSSION}

The product of this research was in the form of marbles game comics based on android using the group investigation model. Products are developed using the 4D development model, with Define, Design, Develop, and Disseminate stages. Products developed before being applied to the field must go through the assessment stage. The assessment is carried out by experts including assessments from several experts in the material field and experts in the media field, physics teachers and peer reviewers. After getting the revised product assessment results according to the suggestions for improvement, then the product will be tested in a limited manner. Limited trials were carried out by looking at the readability of the products developed from the responses of students. Products that have been tested are then revised according to suggested improvements and field trials are carried out. Products that have been tested in the field are revised to produce the final product which will be disseminated later. The following is a description of the results of the stages of product development according to the 4-D model along with the results of the feasibility assessment and student responses.

\subsection{The results of the define stage}

At this stage, several analyzes are produced which are shown in table 2 . The analysis that has been obtained will be used as the basis for making the marbles game comics based on the developed android.

Table 2. Results of the analysis of comic development needs.

\begin{tabular}{|c|c|}
\hline Needs & Result \\
\hline $\begin{array}{l}\text { Features made } \\
\text { according to the } \\
\text { learning model }\end{array}$ & $\begin{array}{l}\text { Introduction, history, topics, } \\
\text { hints, comics, about the } \\
\text { author }\end{array}$ \\
\hline $\begin{array}{l}\text { Software } \\
\text { development }\end{array}$ & CorelDraw X7 and Kodular \\
\hline $\begin{array}{l}\text { The material } \\
\text { according to the } 2013 \\
\text { Revised Curriculum }\end{array}$ & $\begin{array}{l}\text { Momentum, impulse, } \\
\text { impulse-momentum } \\
\text { relationship, the law of } \\
\text { conservation of momentum, } \\
\text { and collisions }\end{array}$ \\
\hline $\begin{array}{l}\text { Characteristics of high } \\
\text { school students }\end{array}$ & $\begin{array}{l}\text { Students are very active in } \\
\text { asking questions and have } \\
\text { high curiosity }\end{array}$ \\
\hline
\end{tabular}

\subsection{The results of the design stage}

At this stage of product design, the initial comic design was prepared based on the definition stage. An android based comic marbles game developed using a group investigation model. The group investigation model has several syntaxes (identifying topics, planning learning tasks, carrying out investigations, preparing final reports, presenting final reports, and evaluating).

Every step of the model group investigation that was in the media features. These features include an introduction feature, a history feature, a topic feature, a hint feature, a comic feature, and an about author feature. The introductory feature contains core competencies and basic competencies. The historical feature contains the introduction of marbles and the procedure for playing video marbles. The topic feature contains the division of physics material topics into two meetings. The help feature contains instructions for using comics. The comic feature contains comic stories that students will read as information gathering. The About Author feature contains the comic designer biography.

\subsection{Result of the development stage}

The development stage is the stage of making a product referring to the storyboard that has been made previously. Comic development was done using CorelDraw X7 and Kodular. This stage produces a product with the .apk extension. This application is 30.17 MB in size and has a main menu display as shown in Figure 2 .

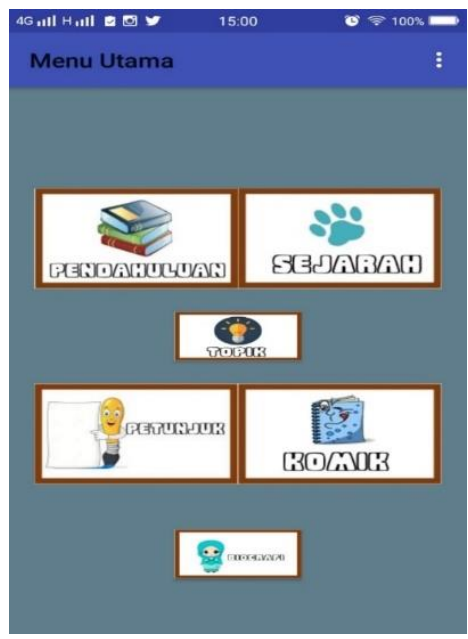

Figure 2. Main menu. 

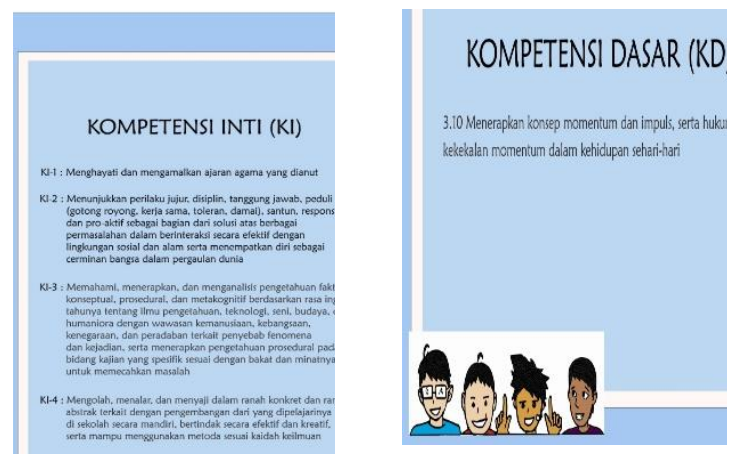

Figure 3. Preliminary features.

Preliminary features such as Figure 3 contain core competencies and basic competencies in the impulsemomentum material.
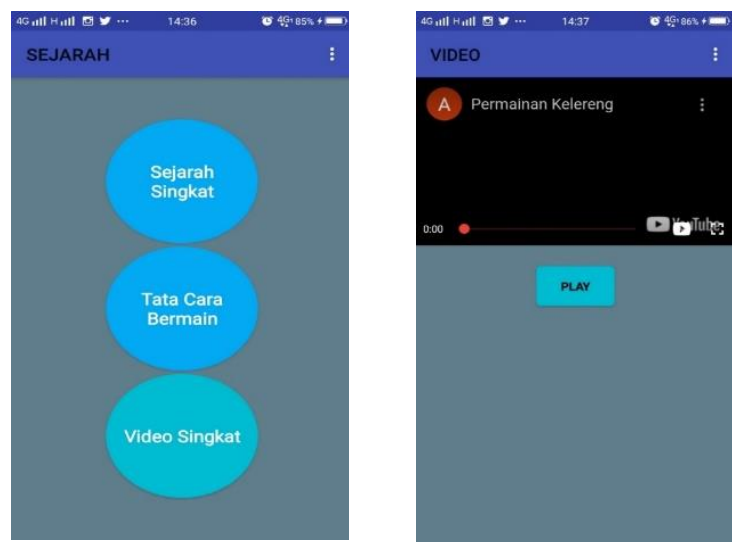

Figure 4. Historical features.

The history feature in Figure 4 contains the history of playing marbles, how to play marbles, and a short video about playing marbles.
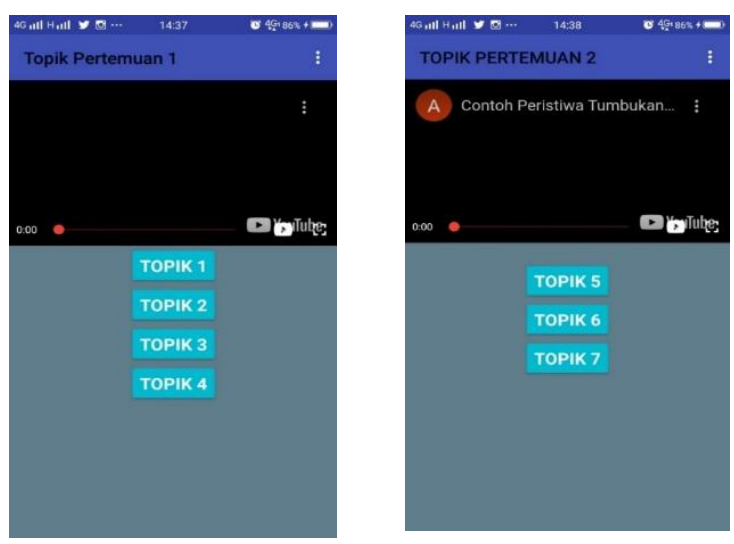

Figure 5. Topic features.

Topic features such as figure 5 contain impulsemomentum material topics in the form of videos as stages of identifying topics in the group investigation model. Students will be asked to choose which topic they like which then groups will be formed according to topics that students are interested in. Next will be given a discussion sheet which will be discussed in the group.

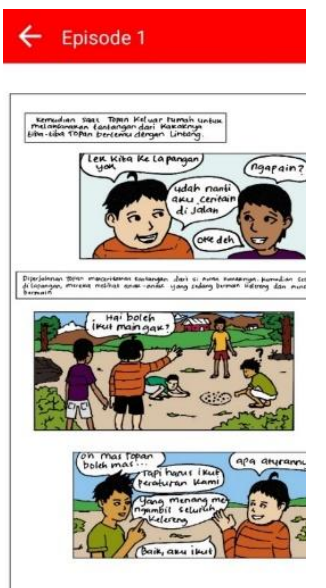

Figure 6. Comic future.

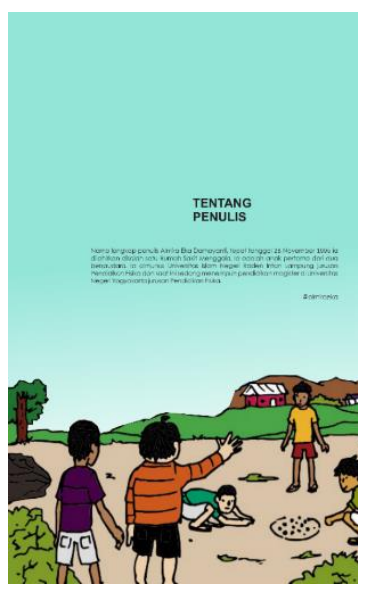

Figure 7. Biographical features.
The comic feature in figure 6 contains comics that are divided into 8 episodes. The content in this comic was developed with an indigenous traditional game, namely the marbles game. The Momentum and Impulse materials developed are arranged according to the competencies to be achieved. Students read comics to get information in conducting investigations to complete discussion sheets. The feature of the author in figure 7 contains the biography of the android comic designer.

The android comics that have been developed are then processed by lecturers including material and media. The feasibility assessment aims to make the comics that have been developed valid for use. The suggestions given will be used as material for application improvements.

Table 3.The results of the assessment of the marbles game comic media product in physics learning material experts.

\begin{tabular}{|r|l|c|c|}
\hline No & \multicolumn{1}{|c|}{ Aspect } & Rating result & Category \\
\hline 1 & Learning & 10,71 & Very good \\
\hline 2 & $\begin{array}{l}\text { Completeness } \\
\text { of Contents }\end{array}$ & 11,29 & Very good \\
\hline 3 & Theory & 11,43 & Very good \\
\hline \multicolumn{2}{|c|}{ Average } & 11,43 & Very good \\
\hline
\end{tabular}

The results of the material expert's assessment of the product developed are shown in table 3, the average obtained is 11.14 with the very good category. 
Table 4. The results of the assessment of the marbles game comic media product in the physics learning media expert.

\begin{tabular}{|c|l|c|c|}
\hline $\begin{array}{c}\text { N } \\
0\end{array}$ & \multicolumn{1}{|c|}{ Aspect } & Rating result & Category \\
\hline 1 & $\begin{array}{l}\text { Quality of } \\
\text { content }\end{array}$ & 11,14 & Very good \\
\hline 2 & Language & 12,00 & Very good \\
\hline 3 & $\begin{array}{l}\text { Implementatio } \\
\text { n }\end{array}$ & 11,00 & Very good \\
\hline 4 & Design & 11,14 & Very good \\
\hline 5 & Visual display & 10,71 & Very good \\
\hline Average & 11,20 & Very good \\
\hline
\end{tabular}

The results of the media expert's assessment of the product developed are shown in table 4 , it was found that an average of 11.20 was in the very good category. This shows that the developed comic media is very good for use based on the judgment of material and media experts such as in research [20]-[22]. It can be concluded that the product in the form of comics for learning physics is suitable for use.

\subsection{The results of the stages disseminate}

This stage is in the form of a wide distribution of products in the form of marbles game comics based on android in physics learning. The dissemination process was carried out by testing the comics that had been developed for 35 SMA class X MIPA students. The results of students' responses to android comics are presented in Table 5.

Table 5. Results of the assessment of students' responses.

\begin{tabular}{|r|l|r|l|}
\hline No & Aspect & $\begin{array}{r}\text { Rating } \\
\text { result }\end{array}$ & Category \\
\hline 1 & Implementation & 8,46 & Good \\
\hline 2 & Completeness of Contents & 8,46 & Good \\
\hline 3 & Theory & 8,80 & Good \\
\hline 4 & Design & 8,74 & Good \\
\hline 5 & Visual display & 8,60 & Good \\
\hline & Average & 8,61 & Good \\
\hline
\end{tabular}

Table 5 shows the results of the assessment of students' responses with an average rating of 8.61 with criteria $8,4 \leq \overline{\mathrm{X}} \leq 10,2$, including the good category. It can be said that the product developed as a physics learning medium is feasible to use. It can be seen from the response of students, students have an interest in Android comics, this is in accordance with the research [23], [24] stated that the use of interesting teaching materials with integrated characters in the form of comics makes students interested in learning.

The results of the research have presented the statement that physics comics based on android are suitable for use in the physics learning process. This statement occurs from several previous studies [25], [12] Physics comic media statement based on android is feasible to be used as a learning supplement for students. This comic media can be used in the learning process both in the classroom and outside the classroom. Physics comic media are arranged in simple language so that students can easily understand the stories in comics.

\section{CONCLUSION}

Figures and tables should be placed either at the top or The marbles game comic based on android using the group investigation model on physics learning is feasible. The product feasibility based on the material expert is in the very good category and the media expert is in the very good category. While the response of students is in a good category. Marbles game comics based on android using the group investigation model which was presented in simple language and attractive appearance made students understand physics material more easily.

\section{REFERENCES}

[1] Marhadini S A K, Akhlis I and Sumpono I 2017 Unnes Physics Education Journal 6(3) 0-5

[2] Liliarti N and Kuswanto H 2018 International Journal of Instruction 11(3) https://doi.org/10.12973/iji.2018.1138a

[3] Syamsuar S and Reflianto R 2018 Jurnal Ilmiah Teknologi Pendidikan

[4] Aljomaa S S, Qudah M F, Albursan I S, Bakhiet S F and Abduljabbar A S 2016 Computers in Human Behavior 61 155-164 https://doi.org/10.1016/j.chb.2016.03.041

[5] Tan W, Hsiao Y, Tseng S and Chan C 2017 Telematics and Informatics https://doi.org/10.1016/j.tele.2017.11.007

[6] Bae S M 2017mChildren and Youth Services Review 81(August) 207-211 https://doi.org/10.1016/j.childyouth.2017.08.01

[7] Setyawan D N, Aminah N S and Sarwanto 2017 Journal of Education and Learning 2 213-8 http://dx.doi.org/10.11591/edulearn.v11i2.6017

[8] Arista F S and Kuswanto H 2018 International Journal of Instruction $\mathbf{1 1} 1-16$ https://doi.org/10.12973/iji.2018.1111a

[9] Ohle A, Boone W J and Fischer H E 2014 International Journal of Science and Mathematics 
Eucation 13 (6) https://doi.org/10.1007/s10763014$\underline{9547-8}$

[10] Resita I and Ertikanto C 2018 Journal of Physics: Conference Series https://doi.org/10.1088/1742$\underline{6596 / 1022 / 1 / 012025}$

[11] Viajayani E R, Radiyono Y and Rahardjo D T 2013 Jurnal Pendidikan Fisika 1(1) 144-155

[12] Hadi W S and Dwijananti P 2015 Unnes Physics Education Journal $\mathbf{4}(2)$

[13] Lestari D I and Projosantoso A K 2016 Jurnal Inovasi Pendidikan IPA 2(2) 145-155

[14] Wati M, Hartini S, Misbah M and Resy R 2016 Jurnal Inovasi Dan Pembelajaran Fisika 157-162

[15] Saregar A 2016 J. ilm. pendidik. fis. Al-Biruni 05 53-60 https://doi.org/10.24042/jpifalbiruni.v5i1.105

[16] Fadilah N U and Suparwoto 2016 J. Inov. Pendidik. IPA 2 76-87 http://dx.doi.org/10.21831/jipi.v2i1.8380

[17] Arinda Y, Wilujeng I and Kuswanto H 2019 International Journal of Educational Research Review 4 (2) https://doi.org/10.24331/ijere.518069

[18] Thiagarajan, Semmel D S and Semmel M I 1974 Instructional Development For Training Teachers Of Exceptional Children: A Sourcebook. Indiana:Indiana University through the genre of the comic book Journal of Surgical Education 71 413418 https://doi.org/10.1016/j.jsurg.2013.11.008

[19] Wiyono K, Ismet I, Murniati M and Zakiyah S 2011 Analisis Konsep Dan Prinsip Fisika Pada Permainan Tradisional Dan Ruang Lingkupnya Pada Materi Pembelajaran Fisika Sekolah Menengah Atas Jurnal Inovasi Dan Pembelajaran Fisika

[20] Astuti I A D, Sumarni R A and Saraswati D L 2017 Jurnal Penelitian \& Pengembangan $\begin{array}{llll}\text { Pendidikan Fisika } & \text { (JPPF) } & \mathbf{3} & 57-62\end{array}$ https://doi.org/10.21009/1.03108

[21] Fatimah F and Widiyatmoko A 2014 J. Pendidikan IPA Indonesia $\quad 3 \quad$ 146-53 http://dx.doi.org/10.15294/jpii.v3i2.3114

[22] Widyawati A and Projosantoso A K 2015 J. Inov. $\begin{array}{llll}\text { Pendidik. } & I P A & 1 & 24-35\end{array}$ http://dx.doi.org/10.21831/jipi.v1i1.4529

[23] Saleh R and Alias N 2012 International Journal of Education And Information Technologies 6 185-197

[24] Hanafi F and Samsudin K 2012 International Journal of Advanced Computer Science and Applications $\quad \mathbf{3} \quad 1-2$ https://doi.org/10.14569/IJACSA.2012.030311

[25] Sari F P, Ratnaningtyas, Wilujeng I, Jumadi and Kuswanto H 2019 IOP Conf. Series: Journal of
Physics: Conf. Series $\mathbf{1 2 3 3} \quad 1-10$ https://doi.org/10.1088/1742-6596/1233/1/012052 